\title{
Review of Green Geosynthetics by Using Biodegradable Resins for Civil Engineering Application as Tailor-Made Materials
}

\author{
Han Yong Jeon* \\ Department of Applied Organic Materials Engineering, Inha University, South Korea
}

Submission: April 18, 2017; Published: June 19, 2017

*Corresponding author: Han-Yong Jeon, Department of Applied Organic Materials Engineering, Inha University, South Korea, Tel: +82-328607492; Fax: +83-328721426; Email: hyjeon@inha.ac.kr

\section{Abstract}

In this study, concept of green Geosynthetics was introduced in terms of biodegradability. Development of green Geosynthetics, its background and technical concerns were discussed through some research results of PLA (poly lactic acid) specimens. Test method for biodegradability of PLA (poly lactic acid) as a green Geosynthetics were considered and suggested based on composting method. Finally, the rest result shows that the concept of biodegradability for green Geosynthetics is available in the environmental application.

Keywords: Green geosynthetics; Biodegradability; Poly lactic acid; Environmental application

\section{Introduction}

For eco-friendly environmental concept in Geosynthetics application fields, "Green" revolution is rapidly increasing in every construction sites in the world e.g., green structure, green installation, green industry etc. especially between construction and society's needs. Furthermore, although durability of Geosynthetics should be emphasized for longterm service period, durability controlled mechanism could be required to fulfil the short-term degradability purpose for green Geosynthetics [1,2]. "Green Geosynthetics" can be defined as following: green Geosynthetics are made of eco-environmental biodegradable polymeric resins or natural materials and they must maintain their needed performance such as durability, design strength, hydraulic property etc. during service period in the application field. Then, after service period they should be degraded no harmful state in the soil structures $[3,4]$. In this article, environmental performance of green Geosynthetics was evaluated and reviewed to be related to the quantitative analysis of biodegradability of green Geosynthetics by conceptual consideration through its evaluation.

\section{Experimental}

Sample preparation: Three types of PLA (PLA 4032D, PLA 6201D; Nature works) and PBAT (poly (butylene adipate-coterephthalate); BASF) were used as additives for performance improvement. Esterase and Phosphate buffered saline powder of $\mathrm{pH} 7.4$ (Aldrich Co.) was used to investigate the degradation behavior. In this study, we used PLA 4032D resin for bleding with PBAT and PLA 6201D was used as reference material for comparison with PLA 4032D. Resins were vacuum dried at $60^{\circ}$ for $4 \mathrm{hrs}$ before usage. Blending was performed with a Brabender Plastic order. Film specimens of PLA and PLA/PBAT blends were prepared through hot pressing under the pressure of $40 \mathrm{~kg} / \mathrm{cm}^{2}$ at $190^{\circ}$

\section{Performance measurements}

Physical properties: The molecular distribution of PLA resins was investigated with gel permeation chromatography (Waters GPC system, 515 pump, 2410 RI detector, Styragel column, PS standard). Tensile properties were evaluated with universal testing machine (Hounsfield, H1000KS).

Hydrolysis properties: To investigate the degradation behavior, strength retention was measured with PLA 4032D and 6201D. Degradation behavior in $0.01 \mathrm{M}$ phosphate buffered saline solution of $\mathrm{pH} 7.4$ was monitored by incubation in a shaking water bath at $45.0 \pm 0.5{ }^{\circ} \mathrm{C}$ for up to 10 weeks. Tensile strength of incubated specimens was measured every 2 weeks using a tensile tester.

Enzymatic degradation: $63.6 \mathrm{mg} / 150 \mathrm{ml}$ enzyme solution for bio-degradable resistance was made by 17 unit/mg of Esterase contained enzyme solution (Aldrich Co.) in $\mathrm{pH} 8.0$ phosphate buffered saline solution. PLA film specimen was 
immersed in this solution for 4 weeks and strength retention was determined using the above equation.

\section{Result and Discussion}

\section{Physical properties of PLA}

As shown in (Table 1), PLA 6201D and 4032D showed similar poly dispersity index (PDI), but PLA 4032D had a slightly higher molecular weight.

Table 1: Mechanical properties of PLA resin (Nature Works).

\begin{tabular}{|c|c|c|c|c|}
\hline Grade & PDI*** & $\begin{array}{c}\text { Tensile } \\
\text { Strength } \\
\text { (MPa) }\end{array}$ & $\begin{array}{c}\text { Elongation } \\
\text { at Break } \\
\text { (\%) }\end{array}$ & $\begin{array}{c}\text { Young's } \\
\text { Modulus } \\
\text { (GPa) }\end{array}$ \\
\hline PLA 6201D & 1.5 & $61.1 \pm 5.2$ & $2.10 \pm 0.10$ & $3.65 \pm 0.09$ \\
\hline PLA 4032D & 1.6 & $64.1 \pm 2.3$ & $2.23 \pm 0.00$ & $3.38 \pm 0.21$ \\
\hline
\end{tabular}

\section{Mechanical properties of PLA blend}
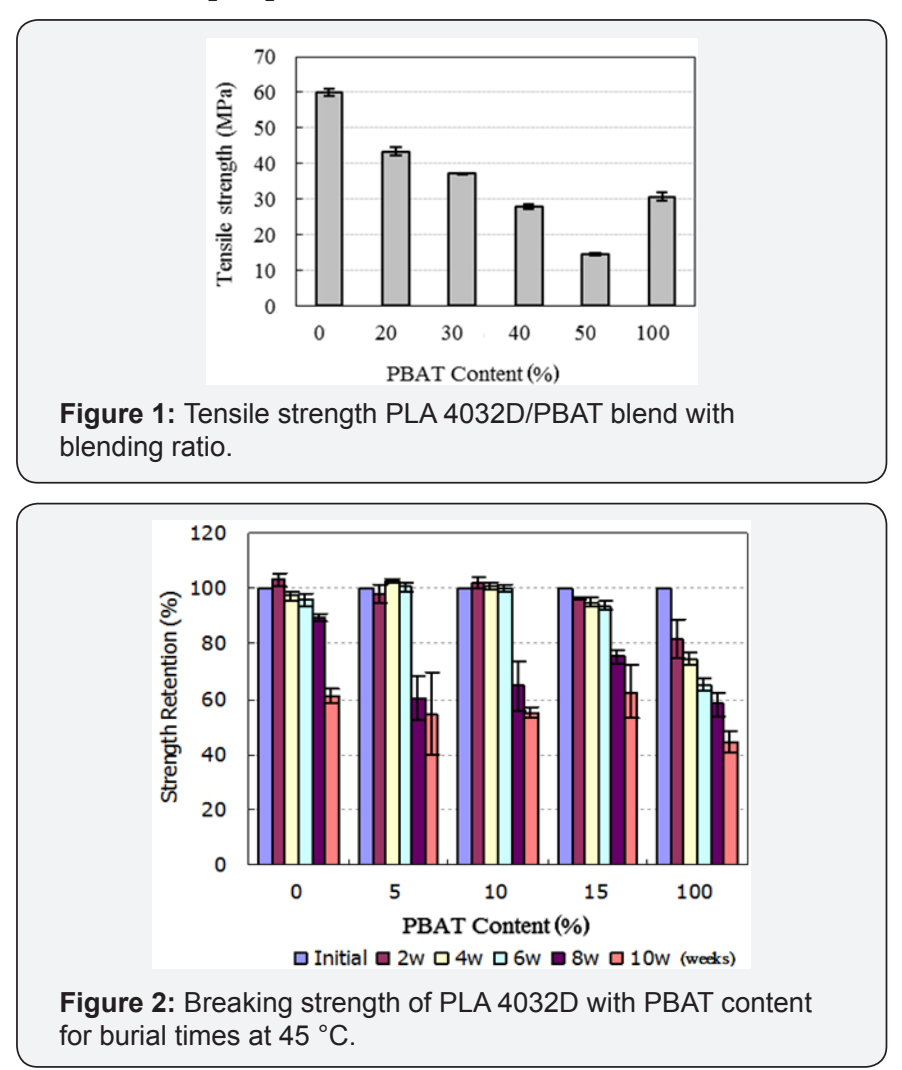

In (Figure 1), tensile strength of PLA 4032D/PBAT blends decreased with increase of PBAT content. Especially, strength retention over PBAT content $40 \mathrm{wt} \%$ was less than that of $100 \%$ PBAT and this is due to compatibility decrease between PLA 4032D and PBAT by compounding. From this, it is seen that brittleness of PLA 4032D could be improved by blending with PBAT. Figure 2 shows the breaking strength of PLA 4032D with exposure temperature. In here, PLA 4032D blends were made to add PBAT which is a kind of biodegradable resin to improve flexibility of green Geosynthetics and strength decrease tendency is seen with PBAT blend ratio and temperature. From the slope of strength decay is very important because degradability control mechanism is determined through the half-life of strength analysis.

\section{Environmental properties of PLA blend}

Figure 3 shows the PLA 4032D specimen burial in soil and this shows strength retention of PLA 4032D under exposure condition and especially under activated sludge burial condition we can find the very rapid strength decay within 30 days. However, PLA shows almost 50\% strength retention in soil burial condition within one year and this means green Geosynthetics of PLA can be available for one year if the strength decay slope could be controlled. To control biodegradability of PLA used green Geosynthetics, more restricted design technology must be adopted in the quality control and assurance of manufacturing and construction procedure in the installation field. Also, Figure 3 shows tensile strength of PLA 4032D specimen which is blended with PBAT content and it is seen that tensile strength decreased with PBAT content. For blending case of 50/50 PLA 4032D/PBAT, tensile strength decreased about $30 \%$ of 100 PLA 4032D used. This means the additive content is a kind of important factor to affect and control the bio-degradability of green Geosynthetics. Table 2 shows interface frictional coefficient between PLA specimen and soil by direct shear test for environmental application as Geosynthetics. In here, PLA 4032D/PBAT (80/20) shows improvement of interface frictional performance than PLA 4032D only used and this is an example of performance improvement by PBAT blending.

Table 2: Interface frictional coefficient between PLA specimen and soil.

\begin{tabular}{|c|c|c|}
\hline \multirow{2}{*}{$\begin{array}{c}\text { Normal Stress } \\
(\mathbf{k P a})\end{array}$} & \multicolumn{2}{|c|}{ Frictional Coefficient } \\
\cline { 2 - 3 } & PLA 4032D & $\begin{array}{c}\text { PLA 4032D/ } \\
\text { PBAT(80/20) }\end{array}$ \\
\hline 50 & 0.665 & 0.718 \\
\hline 100 & 0.642 & 0.703 \\
\hline 150 & 0.613 & 0.692 \\
\hline
\end{tabular}

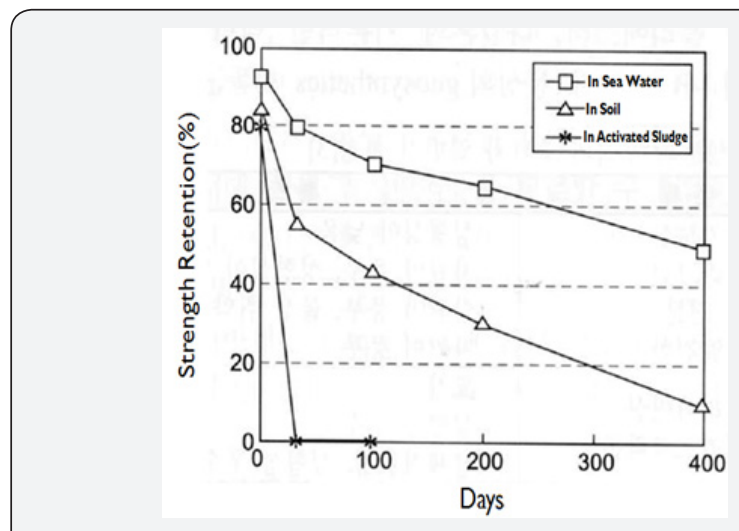

Figure 3: Strength retention of PLA 4032D under environmental exposure condition. 


\section{Proposal of biodegradability evaluation}
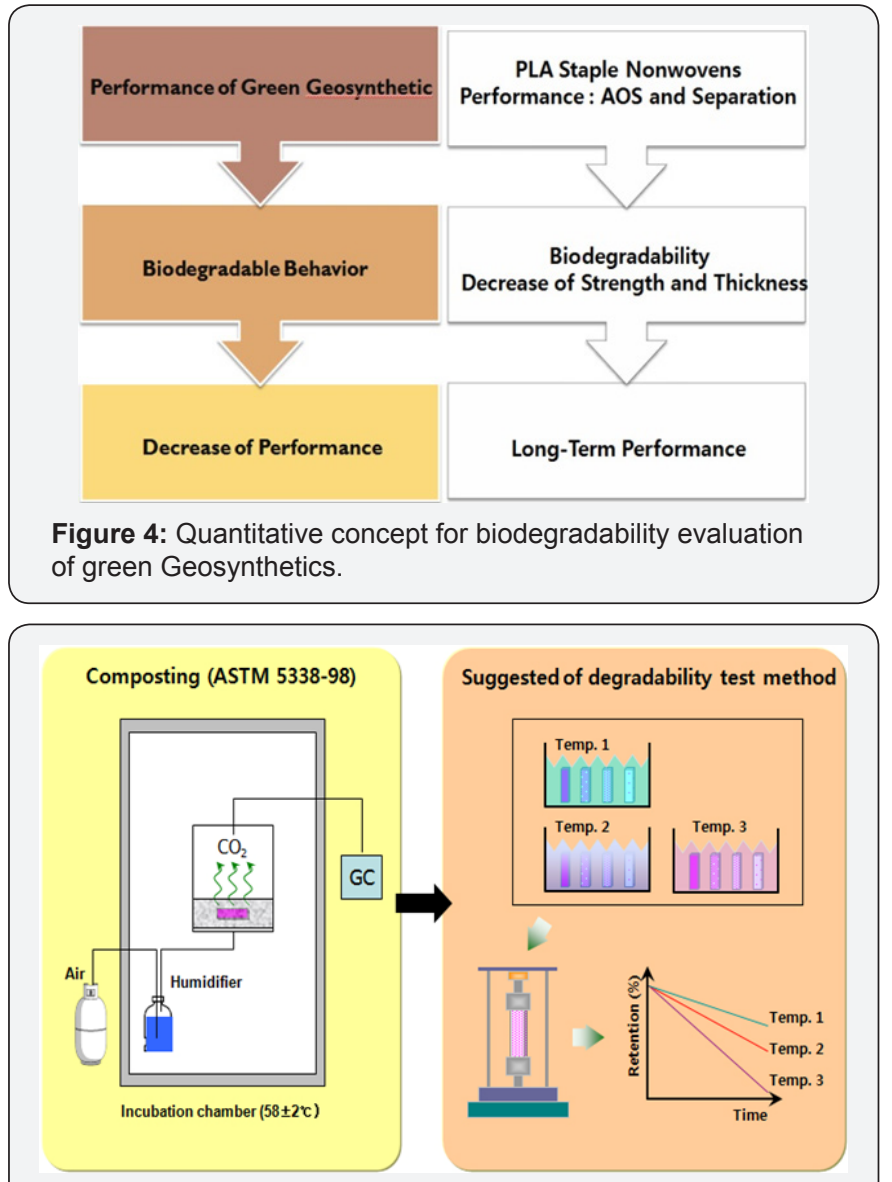

Figure 5: Suggested evaluation procedure of degradability of PLA.

Figure 4 shows the quantitative concept of biodegradability evaluation of green Geosynthetics and the best evaluation items should be selected in accordance with influence parameters which determine the long-term performance under real field installation conditions. In here, we can suggest a kind of hydrolysis method procedure of Figure 5 and this shows the evaluation procedure of degradability of PLA. ASTM D5338-98 (Standard Test Method for Determining Aerobic Biodegradation of Plastic Materials under Controlled Composting Conditions) is introduced to simulate the real installation condition. Through the experimental data analysis, we can suggest the degradability test method with temperature as shown in here. Figure 6 by using Arrhenius plot of accelerated experimental data, we can predict the long-term biodegradable behaviors with temperature and induce this to designing the green Geosynthetics [5].

\section{Conclusion}

Through the overall environmental performance analysis of biodegradability as green Geosynthetics, it is seen that biodegradable mechanism of is possible to control theoretically and to control bio-degradability of PLA used green Geosynthetics. PLA 4032D/PBAT (80/20) blend shows improvement of environmental performance as a green Geosynthetics application than PLA 4032D only used. However, more restricted design technology must be adopted for this and more specific composition and selection of optimum additives of PLA blending should be determined for the quality control of PLA related Geosynthetics. To evaluate the biodegradability of green Geosynthetics performance, new test methods should be introduced and the needed evaluation items should be selected by considering influence parameters on the long-term performance under real field installation conditions.

\section{Acknowledgement}

This work was supported by 2016 INHA UNIVERSITY Research Grant.

\section{References}

1. Shukla K (2002) Geosynthetic and Their Applications. Thomas Telford Ltd, UK, pp. 1-54.

2. Suji T (2008) Degradation of Poly (Lactide)-based Biodegradable Materials. pp. 9-42.

3. Koerner RM (2005) Designing with Geosynthetics. ( $5^{\text {th }}$ edn), Pearson Education Inc, New Jersey, USA, pp. 9-28.

4. Dixson N, Smith DM, Greenwood JR, Jones DRV (2006) GeosyntheticsProtecting the Environment. Thomas Telford Ltd, UK, pp. 93-136.

5. Bastioli C (2005) Handbook of Biodegradable Polymers. Rapra Technology Ltd, India, pp. 57-102.

\section{Your next submission with Juniper Publishers} will reach you the below assets

- Quality Editorial service

- Swift Peer Review

- Reprints availability

- E-prints Service

- Manuscript Podcast for convenient understanding

- Global attainment for your research

- Manuscript accessibility in different formats

( Pdf, E-pub, Full Text, Audio)

- Unceasing customer service

Track the below URL for one-step submission https://juniperpublishers.com/online-submission.php 